\author{
Klaudyna Bociek* \\ Olsztyn
}

\title{
Autonomia jako nadrzędny cel edukacji w ujęciu Aharona Avirama
}

Pojęcie autonomii jest współcześnie jedną z najistotniejszych i najbardziej popularnych kategorii teorii i praktyki życia społecznego, kulturowego oraz politycznego, obecną we wszystkich dyscyplinach nauk humanistyczno-społecznych ${ }^{1}$.

Problematyka niniejszego artykułu zostanie zawężona do obszaru zainteresowań pedagogiki, a konkretnie do zagadnienia autonomii jako celu edukacji. Przedmiotem zainteresowania czyni się koncepcję Edukacji Zorientowanej na Autonomię (Autonomy-Oriented Education) autorstwa izraelskiego filozofa edukacji Aharona Avirama.

Postulat traktowania autonomii jako jednego z naczelnych celów edukacyjnych nie jest zjawiskiem nowym ${ }^{2}$. Psychologowie i pedagodzy, odwołując się zwłaszcza do koncepcji rozwojowych, zwracają uwagę na autonomię

* Mgr Klaudyna Bociek jest doktorantką w Katedrze Pedagogiki Ogólnej Wydziału Nauk Społecznych Uniwersytetu Warmińsko-Mazurskiego w Olsztynie.

${ }^{1}$ B. Wiśniewska-Paź, Kwestia autonomii, wolności i prywatyzacji w kontekście filozofii człowieka, organizacji państwa i edukacji, w: tenże, Autonomia edukacji a ład społeczny. Struktura szkolnictwa w Szwajcarii wobec zdecentralizowanej koncepcji społeczeństwa i państwa. Kwestie porównawcze ze strukturami państw ościennych, Warszawa 2009, s. 37.

2 Zagadnienie autonomii może być rozpatrywane zarówno w kategoriach „celów edukacji”, jak i „,eelów wychowania”. Niniejszy artykuł koncentruje się na autonomii rozumianej w szerszym kontekście - jako cel edukacji, zgodnie z koncepcją Aharona Avirama, który przedstawia wizję całościowej przebudowy systemów edukacyjnych. Poddaje on wnikliwym analizom struktury edukacyjne ponowoczesnych demokracji zachodnich, odnosząc kategorię autonomii nie tylko do procesu wychowania, ale również kształcenia (nauczania i uczenia się), z uwzględnieniem perspektywy jednostkowej oraz społecznej, instytucjonalnej. 
jako na istotną potrzebę życiową już we wczesnej fazie życia dziecka (Erik Erikson) czy jeden z najbardziej pożądanych efektów rozwoju moralnego człowieka (Lawrence Kohlberg, Sergiusz Hessen). Pragnienie wolności i potrzeba samostanowienia są immanentną częścią ludzkiej tożsamości i o ile tę tezę trudno byłoby podważyć, o tyle pogląd postulujący ustanowienie autonomii jednostki nadrzędnym celem edukacji budzi pewne kontrowersje ${ }^{3}$.

Prezentując w niniejszym artykule koncepcję Aharona Avirama, będącą projektem radykalnym i postulatem całościowej zmiany systemu edukacji poprzez uczynienie autonomii wiodącym celem edukacyjnym, wyraża się nadzieję, że debata dotycząca tej kategorii będzie kontynuowana. Zarysowane tutaj podstawy teoretyczne mogą bowiem stanowić wartościowe wskazówki dla praktyki edukacyjnej.

\section{Pojęcie autonomii}

W literaturze pedagogicznej pojęcie ,autonomii” [gr. autos - sam, nomos - prawo] definiuje się jako samostanowienie i samodzielność; najwyższy stopień rozwoju moralnego i jeden z podstawowych celów wychowania. Jednostka autonomiczna natomiast to taka, która podejmuje decyzje, dotyczące zachowania swojego i innych osób w oparciu o własne przekonania ${ }^{4}$. Syntetyczny przegląd różnorodnych sposobów rozumienia autonomii w pedagogice znajdujemy w Encyklopedii pedagogicznej. Możemy dostrzec, że pomimo widocznych różnic, ujęcia te są komplementarne. Autonomia może być zatem rozumiana - za Marią Montessori - jako prawo do wolnego wyboru i samosterowne uczenie się. Alexander Sutherland Neil utożsamia ja z kolei z rozwijaniem silnej, dojrzałej osobowości przez pozostawienie dziecku zupełnej swobody, ograniczonej jedynie przez wolność innych, wyrobienie poczucia wartości czy budzenie uczuć prospołecznych. Rudolf

${ }^{3}$ Obawy krytyków wiążą się być może z brakiem wiary w młodych ludzi (w to, że są gotowi wziąć pełną odpowiedzialność za własną wolność). Wiele osób ma też wrażenie, że o autonomii tak dużo się mówi, iż nie ma potrzeby przypominania, że powinna ona być jednym z najważniejszych celów edukacji („Powinna być, więc na pewno jest”). Pojawiają się również opinie zwolenników „umiarkowanej autonomii”, którzy przyznają, że autonomia istotnie powinna być jednym z celów edukacji, ale nie nadrzędnym (wiąże się to z wiarą, że jeśli każdy nauczyciel będzie pracował z wychowankami ,jak należy”, to autonomia pojawi się jako ,produkt uboczny" procesu wychowania).

${ }^{4}$ B. Milerski, B. Śliwerski (red.), Pedagogika. Leksykon PWN, Warszawa 2000, s. 21. Omówienie kategorii autonomii w naukach społecznych (socjologii, psychologii oraz etyce i filozofii) zob. W. Jedlecka, Podmiotowe ujęcie autonomii, „Przegląd Prawa i Administracji” 66 (2005). Zob. też: B. Wiśniewska-Paź, dz. cyt., s. 37-47. 
Steiner wiąże pojęcie autonomii ze zrozumieniem wolności i integralności innych ludzi, poczuciem pewności siebie i bezpieczeństwa oraz umiejętnością współdziałania z innymi. Zdaniem Tomasza Szkudlarka, człowiek autonomiczny jest naprawdę wolny o tyle, o ile zgadza się poddać zobiektywizowanemu prawu. Jednym z zadań pedagogiki jest wychowanie człowieka autonomicznego, przy czym - jak zauważa Ewa Muszyńska - człowiek ten, sam będąc niezależnym, nie powinien ograniczać autonomii innych ludzi, ale współdziałać z nimi. Lesław Pytka, zwracając uwagę na aporetyczność wychowania, zauważa, że autonomia w relacji edukacyjnej oznacza pewien obszar swobody działania wychowawcy i wychowanka, ograniczany jednak przymusem w wychowaniu. Jednostka oscyluje wówczas między własną niepowtarzalnością i prywatnością a wymogami i oczekiwaniami kontroli społecznej, internalizuje wartości i normy, a - choć utożsamia się z nimi zaczyna działać autonomicznie, ponieważ jej wybory i decyzje wynikają już z mechanizmów samokontrolis.

Analizując pojęcie autonomii jednostki na gruncie psychologii, Kazimierz Obuchowski wyróżnia kilka faz dojrzewania autonomii psychicznej, będącej procesem przechodzenia od fazy pełnej zależności człowieka od otoczenia do fazy pełnej autonomii. W pierwszej fazie - identyfikacji - dziecko utożsamia się z otrzymanymi wzorami zachowań i dzięki nim przyjmuje określony stosunek do wydarzeń. Równocześnie uświadamia sobie własną odrębność i odczuwa potrzebę uzasadniania podejmowanych przez siebie decyzji. Druga faza - kosmiczna - wiąże się z odrzuceniem wzorów identyfikacji, zarysowuje się odrębność człowieka, wzbogaca się jego wiedza o świecie, jednostka tworzy własne koncepcje rzeczywistości i tworzy liczne koncepcje świata i projekty własnego życia $-z$ tego powodu autonomia w tej fazie nie jest stabilna. Hierarchia wartości człowieka podlega modyfikacjom i uzależniona jest od aktualnej sytuacji życiowej jednostki. W trzeciej fazie - dojrzałej - następuje integracja koncepcji świata i wykształcenie się jednorodnych reguł życia, które przekładają się na indywidualne, stawiane sobie przez jednostkę zadania. Stworzony przez człowieka model jest teoretycznie uzasadniony (wynika z wiedzy i zdobytych doświadczeń) i stabilny ${ }^{6}$.

\section{Dwie sfery autonomii}

Mówiąc o autonomii w kontekście edukacyjnym, można za Aharonem Aviramem dokonać rozróżnienia pomiędzy dwiema jej sferami, które na-

${ }^{5}$ B. Jezierska, Autonomia, w: T. Pilch (red.), Encyklopedia pedagogiczna XXI wieku, t. I: $A-F$, Warszawa 2003 , s. 246.

${ }^{6}$ Tamże, s. 244-245; W. Jedlecka, dz. cyt., s. 96-97. 
zywa on „autonomią instytucjonalną” i ,autonomią psychologiczną”. Oba te znaczenia są używane zarówno w języku codziennym, jak i w dyskursie naukowym.

Autonomia w sensie instytucjonalnym dotyczy zakresu niezależności i swobody działania jednostki i grupy, przyznanego im przez jednostkę lub grupę mającą władzę. ${ }^{7} \mathrm{~W}$ rzeczywistości wychowawczej instytucjonalny sens autonomii dostrzec możemy zarówno w odniesieniu do szkoły jako instytucji (w co wpisuje się bardzo popularny współcześnie dyskurs dotyczący demokratyzacji szkoły $)^{8}$ oraz w odniesieniu do związków interpersonalnych, w których jedna ze stron otrzymuje pewien zakres autonomii wolny od interwencji drugiej strony (otrzymuje go albo od drugiej strony - w relacji asymetrycznej, np. dziecko-rodzic, albo za obopólną zgodą - w relacji symetrycznej). W takim zakresie pierwsza strona korzysta z autonomii ${ }^{9}$. Jeśli chodzi o drugie, psychologiczne znaczenie terminu ,autonomia”, dotyczy ono wykazującej określone cechy osobowości człowieka - struktury lub formy jej funkcjonowania ${ }^{10}$. Należy podkreślić, że oba te znaczenia nie łączy żaden związek logiczny, ponieważ jednostka może posiadać autonomiczną osobowość (autonomia w sensie psychologicznym), ale mieć bardzo ograniczony zakres autonomii w swoim życiu (np. osoba z niepełnosprawnością lub więzień), albo odwrotnie - osoba psychologicznie nieautonomiczna może posiadać szeroką autonomię instytucjonalną. Nietrudno jednak zauważyć, że autonomia instytucjonalna tworzy warunki sprzyjające wykształceniu się $\mathrm{i}$ - przede wszystkim - ekspresji autonomii psychologicznej ${ }^{11}$.

7 „Prototyp tego zastosowania dominuje w instytucjach hierarchicznych [...], w których jednostka o większych uprawnieniach przekazuje część swoich uprawnień podwładnym i określa zakres instytucjonalnej rzeczywistości, w której osoby te mogą korzystać z przyznanych im uprawnień. Właśnie $\mathrm{w}$ takich granicach podwładni pozostają autonomiczni. Inną dziedzina, w której termin «autonomia» jest stosowany w podobnym znaczeniu, jest polityka, gdzie grupy dominujące lub sprawujące władzę przyznają narodowościowym lub etnicznym grupom autonomię w pewnych sprawach". A. Aviram, Autonomia i zaangażowanie: dopetniajace sie ideaty, thum. G.T. Wysocka, „Acta Universitatis Nicolai Copernici. Nauki Humanistyczno-Społeczne. Socjologia Wychowania XIV” 339 (2000), s. 87; por. B. Wiśniewska-Paź, dz. cyt., s. 37-38, 41-43.

${ }^{8}$ Zagadnienie to było analizowane w wielu pracach m.in. przez Bogusława Śliwerskiego. Zob. np. B. Śliwerski, Diagnoza uspolecznienia publicznego szkolnictwa III RP w gorsecie centralizmu, Kraków 2013.

9 A. Aviram, Autonomia, s. 87.

10 Tamże.

${ }^{11}$ Tamże, s. 87-88. W tym kontekście dostrzegamy znaczenie i sens propozycji całościowej przebudowy systemu edukacyjnego. Trudno jest bowiem postulować uznanie autonomii jednostki jako jednego z najważniejszych celów wychowania (wychowanie ku autonomii), kiedy sposób funkcjonowania szkoły jako instytucji nie sprzyja realizacji tego postulatu. 


\section{Dwa ideały autonomii}

Drugie rozróżnienie, jakiego należy dokonać mówiąc o autonomii, zachodzi zdaniem Aharona Avirama pomiędzy autonomią jako ideałem życiowym a autonomią jako ideałem edukacyjnym. Wydaje się, że nawet jeśli poddajemy krytyce autonomię w pierwszym znaczeniu, winniśmy ją wspierać w tym drugim, edukacyjnym (co postulował między innymi John White). Różnicę między nimi dostrzegamy szczególnie wyraźnie współcześnie, w rzeczywistości akcentującej relatywizm etyczny, kiedy niemożliwe staje się określenie wspólnej, jednolitej koncepcji „dobrego życia”. Tradycyjnym celem edukacji było przygotowanie ucznia do dobrego życia, jednak obecnie jest bardzo wiele jego koncepcji, odzwierciedlających różne ideologie i światopoglądy ${ }^{12}$. Wydaje się zatem, że jedyne, co podmioty wychowujące moga (i powinny) zrobić, to przygotować ucznia do dokonania jak najlepszego wyboru spośród wszystkich koncepcji dobrego życia. Autonomiczna jednostka będzie w stanie to zrobić. W ocenie Avirama jest to powód, dla którego autonomia powinna być celem edukacyjnym szkoły doby ponowoczesnej ${ }^{13}$. Pogląd ten podziela Zbigniew Kwieciński i stwierdza, że z demokratycznego punktu widzenia rozwój osobistej autonomii jest najwyższym celem wychowania, ale struktura i program szkoły zaprzeczają możliwości realizacji tego celu ${ }^{14}$.

\section{System edukacyjny a rozwój autonomii jednostki}

Struktury edukacyjne dają niewiele przestrzeni dla rozwoju jednostek ku autonomii, ponieważ dominująca w szkole „logika dydaktyczna” opiera się na Zasadzie Jednolitości (Zasadzie Jedności Czasu i Miejsca). Ta „logika dydaktyczna" była odpowiedzią na potrzeby społeczeństwa przemysłowego, kiedy system edukacyjny był zorientowany na socjalizację dzieci do określonych struktur w tych społeczeństwach. Przez ostatnie dwieście lat szkoła realizowała Newtonowską koncepcję absolutnego czasu i miejsca, kontrolując uczestników procesu edukacyjnego w podobny sposób, jak to ma miejsce w więzieniach czy szpitalach, a zatem czyniąc ze szkoły jedną z instytucji totalnych ${ }^{15}$.

12 Tamże, s. 90-91.

13 Tamże, s. 91.

${ }^{14}$ Z. Kwieciński, Autonomia. Aharon Aviram o autonomii jako celu wychowania, w: tenże, Cztery i pót. Preliminaria - liminaria - varia, Wrocław 2011, s. 222.

15 Tamże, s. 223-224. Por. A. Aviram, Personal Autonomy and the Flexible School, „International Review of Education” 5 (1993), s. 423-425. 
Jak zauważa Piotr Kostyło, system edukacyjny jest dysfunkcjonalny zarówno ze społecznego, jak i organizacyjnego punktu widzenia ${ }^{16}$. Nauczyciele funkcjonują w sytuacji paradoksalnej - wymaga się od nich, że będą autorytetami w kulturze, która znosi wszelki autorytet; programy nauczania (zakładające, że wiedza ma wartość sama w sobie) są kwestionowane przez kulturę utylitarną (dla której wiedza musi mieć praktyczne zastosowanie, choćby ze względu na wymogi rynku pracy); reformy pojawiają się nieustannie i często generują zmiany wewnętrznie sprzeczne; różne środowiska mają różne - często sprzeczne - oczekiwania w stosunku do uczniów i nauczycieli; nie istnieje jeden jasny cel edukacji ${ }^{17}$.

Tymczasem, jak stwierdza Zbigniew Kwieciński, logika współczesnego, ponowoczesnego społeczeństwa potrzebuje szkoły bardziej elastycznej i otwartej, przygotowującej młode pokolenie do realnego życia w nowej strukturze społecznej i zachęcającej młodzież do rozwijania swojej autonomii ${ }^{18}$.

Co należałoby zatem zrobić, aby system edukacyjny mógł sprawnie funkcjonować w rzeczywistości ponowoczesnej? Wydaje się, że konieczną staje się zmiana całego systemu i uznanie rangi kultury postmodernistycznej oraz określenie, na czym ma polegać życie w jej ramach. Trzeba wrócić do podstawowych wartości, nie uciekając przy tym od przemian współczesnej kultury, które nie muszą stanowić zagrożenia, lecz być dla procesu wychowania szansą ${ }^{19}$.

\section{Autonomia jednostki jako cel edukacji}

W 1972 roku Robert Dearden opublikował wpływowy artykuł o „nowym celu edukacji”, który miał być związany z innowacyjnością praktyk edukacyjnych, zwłaszcza z nauczaniem zindywidualizowanym (które wykraczając poza sferę dydaktyki - miałoby na celu także wykształcenie w uczniach umiejętności dokonywania indywidualnych wyborów). Nowym celem było zatem rozwinięcie w uczniach szczególnej „,jakości charakteru”, której Dearden nadał nazwę ,autonomii osobowej” (personal autonomy). Po trzydziestu latach od publikacji tego artykułu zagadnienie autonomii osobowej uzyskało stałe miejsce w dyskursie pedagogicznym, stając się central-

16 P. Kostyło, Edukacja Zorientowana na Autonomię, „Kultura i Edukacja” 4 (2011), s. $199-200$.

17 Tamże, s. 201-202.

18 Z. Kwieciński, Autonomia, s. 225.

19 P. Kostyło, dz. cyt., s. 202-203. 
nym motywem wielu ważnych prac z zakresu filozofii edukacji (Eamonna Callana, Johna White'a, Meiry Levinson czy Aharona Avirama) ${ }^{20}$.

Aharon Aviram w wielu swoich artykułach i głośnej książce Żeglując przez sztorm (Navigating Through the Storm. Reinventing Education for Postmodern Democracies), w której przedstawia całościowy obraz edukacji na tle współczesnej kultury zachodniej, zwraca uwagę na rozpad celów edukacji w epoce ponowoczesnej - uważa wręcz, że od dwóch pokoleń tkwimy w czarnej dziurze braku celów edukacji ${ }^{21}$. W swoich pracach Aviram prezentuje postulat uznania autonomii jednostki za nadrzędny cel edukacji. Koncepcję tę nazywa Edukacją Zorientowaną na Autonomię (Autonomy-Oriented Education).

Aviram pokazuje przepaść, jaka dzieli wszystkie aspekty życia człowieka epoki postmodernizmu od stanu, w jakim znajdują się instytucje edukacyjne, przystosowane do poprzedniej epoki. Pomimo obsesji ciagłych „reform" tkwią one w przestarzałych schematach działania i w dawnym paradygmacie ${ }^{22}$. Projekt edukacyjny Avirama, odpowiadający ponowoczesności, prezentuje nowe cele edukacji, zgodne z tradycyjnymi wartościami humanistycznymi. Wartości te mają być nowym drogowskazem, który pozwoli dryfującemu dziś bezładne statkowi edukacji znaleźć właściwy kierunek podczas tytułowego sztormu.

Program przebudowy celów edukacji, postulowany przez Avirama, jest radykalny - to propozycja przejścia od tradycyjnej praktyki wyznaczania celów edukacji przez społeczeństwo (stosowne organy przedstawicielskie) i ograniczenia się do wzmacniania w uczniu jego autonomii. Ten radykalizm nie powinien jednak współcześnie dziwić, jeśli uświadomimy sobie, że system celów edukacyjnych i tak w epoce ponowoczesnej zanika. Postmodernistyczny relatywizm uniemożliwia arbitralne stanowienie celów, które mogłyby być uznane za obiektywne i powszechnie obowiązujące. Czy jednak jest możliwa całkowita rezygnacja z wyznaczania celów edukacji? Aviram zaprzecza. Fakt, że istnieje wiele różnorodnych podejść do zagadnienia celów, nie może skłaniać do rezygnacji z przyjęcia jasnego stanowiska, z wyraźnej odpowiedzi na pytanie: po co uczymy ${ }^{23}$

Aviram przekonuje, że zasadniczym kierunkiem zmiany organizacji edukacyjnych powinno być przejście od rozumienia szkoły jako fabryki wie-

${ }^{20}$ M. Hand, Against autonomy as an educational aim, „Oxford Review of Education” 4 (2006), s. 535.

${ }^{21}$ A. Aviram, Navigating Through the Storm. Reinventing Education for Postmodern Democracies, Rotterdam 2010, s. 45-81.

${ }_{22}$ Z. Kwieciński, Całościowy projekt zmian w edukacji Aharona Avirama, „Kultura i Edukacja” 4 (2011), s. 178.

${ }^{23}$ P. Kostyło, dz. cyt., s. 203-204. 
dzy i dyplomów do postrzegania jej jako ośrodka współpracy i doradztwa $\mathrm{w}$ uczeniu się i rozwoju ${ }^{24}$. Formułuje $\mathrm{w}$ związku $\mathrm{z}$ tym propozycje zmian w zakresie celów działania szkoły oraz programów kształcenia, które generują jednak konieczność radykalnej reorganizacji instytucji edukacyjnych ${ }^{25}$.

W odniesieniu do celów działania szkoły Aviram proponuje dwa cele prowadzące do autonomii. Pierwszym celem jest moralność oparta na trzech filarach, którymi są: kultura humanistyczna Zachodu; uspołecznienie jako dystynktywna cecha gatunkowa człowieka; naturalne i stałe dążenie jednostek do ufności i szacunku do siebie, do własnej samosterowności, spójności, do rozwoju odrębności i samodzielności ${ }^{26}$. Drugim celem jest natomiast dialogiczne bycie, dialogiczność, która wymaga wyćwiczenia się w realizacji następujących zasad: zasady rekoncyliacji (stałego rozpoznawania pluralizmu - dostosowywania się do różnorodności otoczenia społecznego) oraz zasady hermeneutyczności (ciągłej reinterpretacji kultur, światopoglądów i potrzeb innych ludzi $)^{27}$.

W odniesieniu natomiast do programów uczenia się/kształcenia Aviram wyodrębnia siedem domen (obszarów), których uwzględnienie ma służyć zwiększeniu możliwości rozwoju młodych ludzi ku autonomii: 1) niezbędnej wiedzy, potrzebnej do przetrwania i sukcesów w życiu oraz do jej stałego powiększania i użytkowania; 2) rozwijania racjonalnych narzędzi planowania, analizy i krytycyzmu; 3) rozwijania zdolności radzenia sobie w zorganizowanych i społecznych systemach; 4) rozwijania zaangażowania oraz zdolności dokonywania i aktualizowania samodzielnych wyborów, zgodnych z zainteresowaniami; 5) rozwijania zaangażowania oraz zdolności dokonywania i aktualizacji samodzielnych wyborów dotyczących karier zawodowych; 6) rozwijania zaangażowania i zdolności dokonywania samodzielnych wyborów dotyczących społecznych powiązań i aktywności; 7) rozwijania zdolności i zaangażowania jednostek w rozwój autonomii w zakresie podstawowych kwestii egzystencjalnych i kształtu światopoglądu, które warunkują najbardziej zrozumiałe i spójne obramowania dla rozwiązywania innych problemów. Pierwsze trzy domeny dotyczą zatem minimalnych warunków efektywnej aktywności człowieka na wszystkich jej polach, kolejne trzy -

${ }^{24}$ Z. Kwieciński, Odlotowa pedagogia Aharona Avirama. Od „kakofonii w czarnej dziurze" do calościowego projektu przebudowy edukacji w ponowoczesnych demokracjach, w: M. Jaworska-Witkowska, Z. Kwieciński, Nurty pedagogii. Naukowe, dyskretne, odlotowe, Kraków 2011, s. 119; A. Aviram, Navigating, s. 246.

${ }_{25}$ Szczegółowe omówienie charakteru zmian w zakresie organizacji edukacyjnych zobacz w: A. Aviram, Navigating, s. 209-246.

${ }^{26}$ Z. Kwieciński, Pedagogie postu. Preteksty - konteksty - podteksty, Kraków 2012, s. 405; A. Aviram, Navigating, s. 203-207.

${ }^{27}$ Tamże. 
ukonstytuowania istoty własnego człowieczeństwa, natomiast ostatnia wiąże się z samookreśleniem indywidualnego stylu życia jednostki i sensu życia, a także aspiracji dotyczących własnej tożsamości ${ }^{28}$.

Paradygmat Edukacji Zorientowanej na Autonomię jest nastawiony na wzmocnienie autonomii, moralności i przynależności w młodych ludziach ${ }^{29}$. Autonomię budują autentyczność i samosterowność. Autentyczność jest tu rozumiana jako zdolność człowieka do uświadamiania sobie własnych zainteresowań, talentów, uczuć i pragnień oraz stylów aktywności. Samosterowność natomiast dotyczy zdolności jednostki do racjonalnych form planów działań i realizowania ich. Termin ten jest silnie powiązany z racjonalnością i dojrzałością emocjonalną. Człowiek autonomiczny jest zatem zdolny rozpoznawać swoje zainteresowania, tworzyć racjonalne plany ich realizacji, a jako osoba dojrzała emocjonalnie, jest również zdolny do realizacji swoich zainteresowań i planów, pomimo pojawiających się przeszkód. Moralność natomiast jest tutaj rozumiana jako świadomość człowieka, że należy unikać działań, które krzywdzą innych ludzi. Z kolei przynależność jest postrzegana jako jednostkowa koncepcja siebie samego jako osoby będącej zaangażowaną w grupę lub grupy społeczne ${ }^{30}$. Zarówno moralność, jak i przynależność wynikają z wartości autonomii i są niezbędne do jej realizacji. Edukacja ku moralności zapewnia poszanowanie prawa innych do bycia autonomicznymi, natomiast edukacja ku przynależności wyrasta z edukacji ku autonomii z kilku powodów: 1) edukacja ku ideałowi autonomicznej osoby jest $\mathrm{w}$ sposób nieunikniony związana z przynależnością do zachodniej kultury humanistycznej, w której ten ideał się rozwinął; 2) społeczno-kulturowe ramy zapewniają niezbędne doświadczenia, za którymi jednostki mogą podążyć lub którym mogą się sprzeciwić; 3) przynależność do stabilnej społeczno-kulturowej ramy (rodzina, społeczność) w okresie dzieciństwa jest konieczna dla kształtowania pozytywnego obrazu siebie samego, bez którego samosterowność i autonomia są niemożliwe ${ }^{31}$.

${ }^{28}$ Z. Kwieciński, Odlotowa, s. 118-119; A. Aviram, Navigating, s. 215-226.

${ }^{29}$ Są to trzy podstawowe wartości edukacyjne liberalnej demokracji i humanizmu, mające swoje korzenie w myśli XIX-wiecznych niemieckich humanistów. Wpływ tej tradycji można również dostrzec we współczesnych podejściach, np. psychologii humanistycznej. Aviram opiera swoją koncepcję autonomii i koniecznego do jej osiagnięcia procesu dydaktycznego przede wszystkim na poglądach Johna Stuarta Milla. A. Aviram, Beyond Constructivism: Autonomy-Oriented Education, w: I. Gur-Ze'ev (red.), Conflicting Philosophies of Education in Israel/Palestine, Dordrecht 2000, s. 480.

${ }^{30}$ Tamże, s. 480-481.

31 Tamże, s. 481. 
W projekcie Edukacji Zorientowanej na Autonomię Aharona Avirama chodzi zatem bardziej o określenie drogi ku celom, a nie samych celów ${ }^{32}$. To cel formalny - gwarantuje jednostce możliwość wyboru, nie przesądzając, jaki ten wybór powinien być33. Warto jednak podkreślić, że orientując edukację na autonomię jednostki, musimy się liczyć z wszelkimi konsekwencjami przyjęcia tej strategii, także z tym, że uczeń korzystając z autonomii dokona wyborów, które ograniczą lub pozbawią go autonomii. Używając osobliwej metafory, można powiedzieć, że wychowanie do autonomii jest jedynie „trampoliną”, z której uczeń może „wybić się” do wybranego przez siebie „ideału życia”, a zatem również zrezygnować $\mathrm{z}$ autonomii, jeśli wybrany ideał stoi $\mathrm{z}$ nią $\mathrm{w}$ sprzeczności. Nie musi to bynajmniej oznaczać, że wybór ten będzie nieodwołalny jednostka, która raz przyswoiła sobie postawę autonomiczna, nigdy jej nie traci -w każdej chwili może wrócić na trampolinę i powtórzyć skok ${ }^{34}$.

\section{Uwagi końcowe}

Jak zauważa Tomasz Szkudlarek, „myślenie edukacyjne - w różnych jego odmianach - zawsze odnosiło się jakoś do kwestii wolności, czy to pojmowanej jako autonomia osoby dojrzewającej przez kontakt $\mathrm{z}$ wartościami kultury, czy jako możność wyboru zadań realizujących potencjał rozwojowy jednostki, czy wreszcie jako naturalne i nienaruszone prawo dziecka do samostanowienia" 35 . Autonomia, kojarzona ze swobodą, wolnością i niezależnością, może być jednak przez niektórych traktowana jako zagrożenie czy nawet zamach na proces wychowania. Pojawia się obawa, że nadmierna ofiarowana dziecku swoboda może uczynić proces wychowania - często tradycyjnie utożsamiany jedynie $\mathrm{z}$ jednokierunkową transmisją wiedzy i wartości - niemożliwym. Tymczasem, jak zauważa Józef Tischner, wolność (odpowiedzialna, uwzględniająca wolność Innego) przynależy do „substancji etycznej" człowieka i jego wspólnoty. A zatem wolności nie należy się obawiać, lecz przygotować do niej wychowanków. I tak jak istotą człowieka jest wolność, tak też istotą oddziaływania pedagogicznego - jak się wydaje powinno być wychowanie do wolności, ponieważ „autentyczne wychowanie jest zawsze wychowaniem wolnego człowieka" ${ }^{36}$.

${ }^{32}$ P. Kostyło, dz. cyt., s. 205.

33 Tamże, s. 207.

${ }^{34}$ A. Aviram, Autonomia, s. 90-91; P. Kostyło, dz. cyt., s. 207.

35 T. Szkudlarek, Wolność ponowoczesna i pedagogika dekonstrukcji, w: M. Reut (red.), Dylematy wolności, Warszawa 2001, s. 225.

36 D. Wajsprych, Pedagogia agatologiczna. Studium hermeneutyczno-krytyczne projektu etycznego Józefa Tischnera, Torun-Olsztyn 2011, s. 299. 
Koncepcja Edukacji Zorientowanej na Autonomię stworzona przez Aharona Avirama przedstawia radykalną wizję edukacyjnej zmiany i jako taka zyskuje sobie zarówno wielu przeciwników, jak i apologetów. Trudno wierzyć, by ten model był możliwy do pełnej implementacji na gruncie polskim. Jego prezentacja wydaje się jednak sensowna, ponieważ wyraża powszechne wśród ludzi (bez względu na wiek) pragnienie wolności, zwracając jednocześnie uwagę na fakt, że nie urzeczywistni się ona w pełni, jeśli zostanie przyjęta bez odpowiedzialności. Ustanowienie autonomii jako nadrzędnego celu edukacji wiąże się w ujęciu Avirama z przeświadczeniem, że wolność o wiele bardziej niż „,daną”, winna być w procesie edukacji wartością „zadaną". Warto postulować, by w uświadomieniu sobie i realizacji tego zadania pomagali sobie wzajemnie wszyscy uczestnicy procesu edukacyjnego.

\section{Autonomy as an Overriding Educational Aim in Aharon Aviram's View (Summary)}

The article refers to the issue of autonomy as an overriding educational aim and is analyzing the concept of Autonomy-Oriented Education (AOE) by the Israeli philosopher of education, Aharon Aviram. Although the desire for freedom and the need for self-determination is an immanent part of human identity, the project of erecting individual autonomy as a central educational aim is a matter of controversy.

According to Aviram the autonomy should be the main educational goal, and postmodern school should encourage young people to develop their personal autonomy, morality and dialogical belonging - three basic humanistic values. To accomplish that, Aviram proposes a total change of the prevailing education system. This paper presents an overview of the assumptions of that conception.

Keywords: Autonomy-Oriented Education; individual autonomy; personal autonomy; morality; educational aims.

\section{Autonomia jako nadrzędny cel edukacji w ujęciu Aharona Avirama (Streszczenie)}

Artykuł dotyczy zagadnienia autonomii jako nadrzędnego celu edukacji i prezentuje koncepcję Edukacji Zorientowanej na Autonomię izraelskiego filozofa edukacji, Aharona Avirama. Chociaż pragnienie wolności i potrzeba samostanowienia 
stanowią immanentną część ludzkiej tożsamości, projekt ustanowienia autonomii jednostki nadrzędnym celem wychowania budzi pewne kontrowersje.

Zdaniem Avirama autonomia powinna być zasadniczym celem wychowania, a ponowoczesna szkoła winna wspierać młodych ludzi w kształtowaniu ich osobistej autonomii, moralności i dialogicznej przynależności - trzech podstawowych wartości humanistycznych. Aby to osiąnąć, Aviram proponuje całościową zmianę dominującego systemu edukacyjnego. Niniejszy artykuł prezentuje zarys założeń tej koncepcji.

Slowa kluczowe: Edukacja Zorientowana na Autonomię; autonomia jednostki; autonomia osobowa; moralność; cele edukacji. 